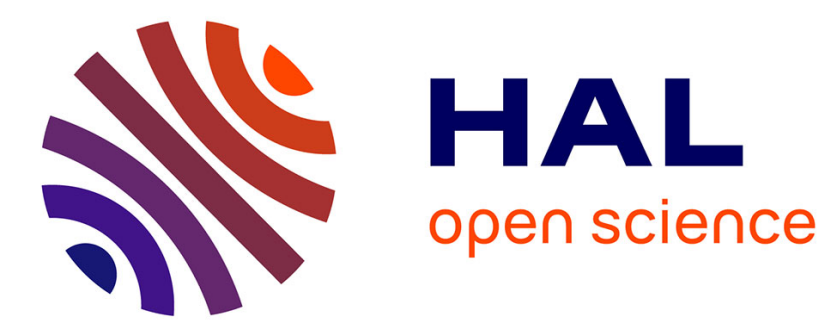

\title{
Universities and Pricing on Higher Education Markets
}

\author{
Christine Musselin
}

\section{To cite this version:}

Christine Musselin. Universities and Pricing on Higher Education Markets. Mattheou, Dimitris. Changing Educational Landscapes. Educational Policies, Schooling Systems and Higher Education A Comparative Perspective, Springer, pp.75-90, 2010. hal-00972724

\section{HAL Id: hal-00972724 \\ https://hal-sciencespo.archives-ouvertes.fr/hal-00972724}

Submitted on 3 Apr 2014

HAL is a multi-disciplinary open access archive for the deposit and dissemination of scientific research documents, whether they are published or not. The documents may come from teaching and research institutions in France or abroad, or from public or private research centers.
L'archive ouverte pluridisciplinaire HAL, est destinée au dépôt et à la diffusion de documents scientifiques de niveau recherche, publiés ou non, émanant des établissements d'enseignement et de recherche français ou étrangers, des laboratoires publics ou privés. 


\title{
Universities and pricing on higher education markets
}

\author{
Christine Musselin \\ Centre de Sociologie des Organisations (Sciences Po et CNRS) \\ 19 rue Amélie, 75007 Paris - France \\ Tel : 0033140626570 - Fax : 0033147053555 \\ c.musselin@cso.cnrs.fr
}

It is more and more frequent to read that higher education is being transformed into an industry (or should be turned into an industry, European Commission 2005) and that market forces are driving the development of higher education systems.

Two main arguments are generally mobilised to document this evolution. The first one deals with the transformation in the nature of the products provided by higher education institutions. A few decades ago, it was generally taken for granted that training and research are (or should be) common goods, i.e. goods that are non-rival (their consumption do not prevent consumption by others) and non-excludable (those who do not pay for it may nevertheless consume it). As a result, the idea that training should be accessible to the largest share of the population and that the cost for massification should be born by the society at large because it benefited the society at large, was dominant in many countries. Massification and free access became a motto. Research discoveries were not the ownership of those who were the authors but should benefit everyone and be diffused freely. Of course, there existed many exceptions to this general trend. In countries like the USA for instance, private higher education institutions developed before public universities and families were accustomed to the idea of paying for their children's university education. Another exception was provided by the restrictions in the diffusion of sensitive research results in nuclear physics which 
occurred because of conflicts between large regions of the world (Mallard 2006). But exceptions today tend to be the rule and this evolution is supported by the development of new discourses and rationales. On the one hand, the failure of free access in achieving democratisation and the argument that the lower and low middle classes are paying for upper and upper middle class children who attend higher education, provided grounds for the introduction of fees. It is therefore argued that the collective gain expected by the society from the individual training of a student was lower than the personal gain this student could expect for him/herself in acquiring a university degree. He/she should then pay for this investment in human capital. On the other hand, the potential applications derived from fundamental research and their transformation into innovation and industrial products led to the extension and generalization of intellectual property rights in order to protect the use of new applications and generate funding for those who developed them. As a result, contractual research expanded and the products of these contracts are no more considered as non-rival and non-excludable: delays for their diffusion may be introduced and access to them may be restricted by patenting and licensing agreements.

This evolution in the conception of training and research as well as in concrete practices leads some authors to argue that higher education is undergoing a process of marketisation (Charle and Soulié 2008) and that academic capitalism (Slaughter and Leslie 1997; Rhoades and Slaughter 2004) is expanding. According to them seeking profit becomes more and more important in academic life thus leading academics to adopt economic behaviours and norms.

Along with this first argument based on the transformation of training and research into private goods, a second argument points at the transformation of the national higher education systems into highly differentiated systems providing the basis for the emergence of different 
competition sets (Lant and Baum 2003). This process first of all concerns continental Europe where university systems developed according to a predominantly egalitarian rhetoric. France is probably the most representative of such egalitarian models where each university was supposedly equal to the other ${ }^{1}$, thus delivering the same degrees (as guaranteed by the agreement delivered each four years by the national ministry), allocating public funding all on the same basis (through a mathematical formula), etc. Of course this equality was more hypothetical and declared than real (the degrees granted by a Parisian university often had more prestige) but all higher education policies explicitly aimed at safeguarding and reinforcing the egalitarian principles (Musselin 2001/2004, chapter 4). This is no more the case (Aust and Crespy forthcoming), in France as in other continental European countries as well. In the 1990s, universities have been asked to become "organisations" (Brunsson and Shalin-Andersonn 2000, Musselin 2007, Krücken and Meier 2006) and to highlight what makes each of them special, different and attractive. Asked to write strategic plans and mission statements, each institution is no more urged to demonstrate its conformity with the national system but to point out its strengths and differences with others. In the 2000 s, the identification of few universities selected to receive massive funding is becoming the norm as can be observed in Germany with the Exzellenzinitiative or in France with the Plan Campus ${ }^{2}$. Universities are thus encouraged to compete with one another and to identify/choose their profile. Population ecologists would say they are defining their niches and neoinstitutionalists would speak of the emergence of competition sets. In more banal terms, one describes this evolution as the development of a market.

My point here is neither to contest the reality of the evolution described above, nor to judge them and decide whether they are good or not. It is rather to discuss the fact that in order to describe these trends, it becomes trivial to say that there exists a "market" of higher education. 
While it is certainly useful and relevant to use the term market as a metaphor, one should nevertheless wonder whether it is analytically well suited. Or, to put it another way: one should at least define what is understood by the term market and question when and how this definition authorizes us to speak of markets (and thus of marketisation) in higher education. This is what will be done in the first section of this paper: I will propose a definition of the market and, building on it, I shall identify two domains where market relationships are developing (at least in some countries). The more precise question addressed in the following sections will then be: what can we say about the behaviours of universities on these markets? What are their specificities? How can they be characterized?

\section{A. Marketisation versus increased competition?}

The main argument in this first section is that we should be more careful in the use of the word "market" in terms of higher education and first define this notion, and then consider how it applies to higher education.

There are of course many definitions of what a market is. As stated by P. François (2008: 60) some definitions point at the formal characteristics of a market while others focus on the contents of the relationships, but the strength of the definition of markets by M. Weber (1995/1922) is to simultaneously consider the form and the contents. R. Swedberg (1998: 43), points at the same conclusion when he writes that "the heart of Weber's analysis of the market consists of the idea that its core is made up of one type of economic action -exchange- which is simultaneously oriented in two different directions: toward one's exchange partner ('struggle over the price') and toward one's competitor ('struggle between competitors')". 
Thus "market is different from other forms as it is the layout of two sets of interactions, an interaction of exchange and an interaction of competition" (François 2008: 60).

According to this definition these two main mechanisms have to be simultaneously present in order to speak of market. Suppliers have to compete one with another to obtain access to buyers, while buyers compete one with another to get access to suppliers, and there must be an economic relationship between a buyer and a supplier.

One of the consequences of this definition is that exchange without competition, and competition without exchange should not be called a market. It is therefore excessive for instance to speak of a market for grants in higher education. It is "only" competition: when different research councils or foundations launch calls for proposals, project leaders are competing one with the other to obtain funding while research funders are competing one with the other to attract the best projects but no exchange follows this process. Funding agencies allocate an amount of funding but there is no negotiation or "struggle". Conversely, it is excessive to describe the introduction of contractual agreements to allocate public funding as a market-mechanism. In such contractual processes, there is exchange but no competition among suppliers (there is only one: the concerned public authority) and no competition among buyers (they all have access to the supplier and first have to convince him to fund their project during the exchange relationships).

By contrast, some other situations can be qualified as markets in higher education according to Weber's definition, at least in some countries. Two of these situations are expanding today and are of high relevance. The first one concerns the recruitment of academics in countries where there is a negotiation with the candidate being recruited on his/her "price" 3 ". This is not 
the case everywhere. While in all places (or almost all) there is competition (competition among universities to attract the best candidates, and competition among the latter to obtain access to the best universities), exchange on the "price" at which the recruitment will be concluded only occurs in some countries ${ }^{4}$. But when competition and exchange interactions occur simultaneously, we shall speak of a market for professors.

The same holds true for tuition fees when they are set by the individual institution and are considered as a total or partial equivalent to the training provided for the fees. Again, there exists competition for students almost everywhere in the world ${ }^{5}$, but exchange is rarer and occurs only in countries where fees vary. In these countries, it is relevant to speak of a market for students: universities can select their students and students compete for access to universities and the service delivered by the university is identified with a "price" which differs from one university to another.

The definition of the market which we suggest is therefore more powerful in order to discriminate among situations. It also helps to identify the degree of diffusion of market relationships in higher education. As noted for recruitments and fees, it is only in some countries that we can speak of a market for professors or for students. The existence of fees or hiring processes is not sufficient per se.

In these two cases, it is the existence (or absence) of the exchange process which allows (or prevents from) speaking of a market. Therefore we will concentrate on exchange rather than on competition in the rest of this paper and more precisely focus on pricing. In other words, we will look at how universities define the price they offer a professor and how they set the level of fees they require from their students. These are the two points which will be 
developed in the next two sections, in order to explore the nature of the markets in which universities are involved and their behaviours as economic actors.

\section{B. How do universities set the price of a professor?}

To investigate how universities set the price of their academic staff, I will mainly rely on a study I led on recruitment processes in France, Germany and the United States (Musselin 2005), focusing only on the last two countries, i.e. the two in which competition and exchange $e^{6}$ can be observed.

The study relies on in-depth interviews led in 22 departments (11 in History and 11 in Maths) in the three countries (10 in France, 8 in Germany and 4 in three American private research universities). The aim of this research was threefold. First, it consisted in studying how academic positions are managed (created, suppressed or reoccupied when vacant) in the three countries. Second it was intended to understand how hiring committees make decisions and rank candidates. Third, in Germany and the United States, it also focused on the negotiation which takes place between the university and the candidate who is ranked first.

Three main results will be discussed here. First I will argue that the market for professors is an "economy of quality", i.e. a market where quality, not pricing, is the operator through which supply meets demand. Second I will question how this pricing occurs on such markets and show that there exist quite different mechanisms in the two countries under study. Third, I will discuss the specific relationships between quality and price on these markets. 


\section{a) Academic labour markets as an economy of quality}

The notion of economy of quality (or economy of singularities) has been developed by the French sociologist Lucien Karpik (1989, 1995, 2007) since the late 1980s. Looking at the importance of quality on market relationships was already common in economics in papers focusing on the effects of asymmetric information, the information on the "real" quality of a good (or the real competence of a person) being one of the causes for asymmetry. The fundamental contribution of L. Karpik is to refuse to consider such situations as deviant variations of perfect markets. He argues that this is an alternative form of market characterized by the fact that quality, not pricing, allows supply and demand to meet. For Karpik, this happens in exchange situations where uncertainty on the quality of the supply side is high.

L. Karpik developed this notion in a seminal paper published in 1989 , where he tried to understand how lawyers who are not allowed to advertise by providing information about their previous accomplishments or the place where they were trained, may attract clients who beforehand had no information about the quality of the lawyers (Karpik 1989). He showed that confronted with this uncertainty, clients utilized personal networks to make up their mind and identify a reliable lawyer. As a result, it is only in a second period of time, after the supply (lawyer) and the demand (client) have met that a price is set. In a last part of the paper, Karpik explains how this price is determined and why the lawyers propose reasonable honorariums despite the fact they could overestimate them, as they benefit from a situation of asymmetric information over their clients. 
The distinction between the match of supply and demand, and the process of pricing, as well as the uncertainty on the quality of the candidates, are also observable in the area of academic labour markets (Musselin 1996). They are therefore a form of economy of quality. In the countries under study, two different phases, run by different actors can be identified. First a phase of judgement, characterized by the fact that the peers assess the quality of the applicants and come to a ranking. Supply and demand have met. Second a phase of negotiation on the price offered to the candidate ranked first: the main actors of this phase are the candidate and the university leadership and they set a price. As for the lawyers, quality is the main operator for the supply to meet the demand. Pricing comes next.

Following L. Karpik's conclusion, I thus argue that academic labour markets are a specific kind of market. Yet this notion of economy of quality raises an interesting puzzle about pricing. If the price is not the operator (and thus is not set when supply meets demand), how is the price set? While Karpik raised and discussed this point in his paper, most of the authors working on quality issues focus on the first face of the puzzle, i.e. how to make a judgement and overcome the uncertainty on quality. They surprisingly neglect pricing (Musselin and Paradeise 2002). This is precisely why I will now raise the following question: how is a price determined if you already know the result of the match between supply and demand?

\section{b) Different mechanisms of pricing}

The comparison between Germany and the United States first reveals that pricing mechanisms vary from one country to another. There is not one single and common way to set the price of academics in countries where there is a market for professors. 
In Germany, the study was led before the important reforms introduced in 2002. Before mentioning the transformations introduced by the latter, let me sum up the main characteristics of the negotiation process by the late 1990s. It is important to start by mentioning the narrowness of the field of negotiation because of the many restrictions delimiting it. Such processes only occur for the tenured professors and among them primarily for the full professors. They concern the working conditions and almost never the salaries, the latter being set according to salary scales. The possibility to outbid competitors is also restricted: a professor is allowed to negotiate with his/her university and with the recruiting institution but if many universities ranked him/her first he/she can not simultaneously negotiate with all of them and have them compete for him/her. As a result, the scope of negotiation is furthermore contained.

The negotiation is then closely linked to the situation of the recruiting university and to the "standards" the latter has developed. Most of the time, there exists a sort of tariff the institution had agreed upon, setting the average package (number of assistant positions, budget for books, etc.) to be offered according to the concerned discipline and to the status (full professor or not) of the candidate. The possibilities for deviation are rather limited. There must be exceptional circumstances for the institution to propose much more/less. Therefore I suggest speaking of the "price of the institution" in the German case.

Up to recently, this price (i.e. the working conditions package) worked as an investment, or a bet, made by the university. The package offered by the institution during the recruitment negotiation process was attributed whatever happened next. If the professor decided not to work intensively anymore, the university had made the wrong investment. If the professor obtained impressive results, the university was right in making this investment. The university 
could not come back on the decision it took. The only possibility for renegotiating was in the hands of the professor: he/she could apply for another position and if he/she were ranked first, he/she could renegotiate or leave. His/her university could then decide to invest again and more (and try to keep the professor by offering as much as the recruiting university) or not.

The reforms introduced since 2002, have transformed this system of pricing in different ways. First some of the existing restrictions have been relaxed. The introduction of merit-salaries for instance allows for negotiations on salaries ${ }^{7}$ and part of this salary is merit-based. Second the negotiated price (in salaries and in working conditions) can be regularly renegotiated. This means that internal labour markets (Doeringer and Piore 1971) have been developed in German universities and that the negotiation of the price is becoming one of the instruments of these internal markets (Musselin 2004). Nevertheless, the price set during the recruitment remains first of all the price of the institution ${ }^{8}$.

In the United States, by contrast, one must speak of the "price of the market" and the scope of negotiation is by far less contained than in Germany (Sørensen, 1993). Such negotiations occur for all tenure track positions (not only for tenured positions); the candidates may outbid if they have different offers; the price includes the salary, working conditions, personal benefits etc. What happens when an assistant professor ${ }^{9}$ is recruited and how is this price set $^{10} ?$.

It is first interesting to note that there is no direct negotiation between the candidate ranked first and the university. This negotiation happens between the chair of the recruiting department and the dean. As a result, the former is interested in getting the highest price for the candidate for two reasons. First, the chair wants the candidate to remain in the long run. If 
the price is too low, he/she will be tempted to leave the university very soon, thus provoking a new deal with the dean about the position, a new application, a new recruitment process, etc. Second, if the price is high, the chair will be able to negotiate a salary increase for all academics of the department in order to adjust. The dean knows that he/she can not make too low an offer because he/she risks losing the candidate, but also he/she also wants to limit the level of price, knowing the consequences it may have. Nevertheless, there is clearly a rather inflationist game situation.

Nevertheless, the dean and the chair do not negotiate from scratch. For the salary part of the price for instance, they rather start from the "price of the market" and have to decide how much they go upper or lower this level. The "price of the market" consists of the salary proposed by departments of the same discipline which the chair and the dean consider as equivalent in reputation and quality to their department. This list of "equivalent" departments is not official and formal. It is "common knowledge" among the members of the same department. They have an idea of the salaries in the departments they consider as equivalent. The way they know about it is very informal. They call a colleague they know well, or have informal talks during conferences etc. Thus, as the producers described by H. White (1981), they observe one another and set their salaries according to what the others practice.

The non-salary part of the price follows by contrast a more open process. There is indeed an average package which the chair and the colleagues of the department tell the candidate he/she can request but there are also possibilities to negotiate for specific elements which are directly linked to the individual situation of the candidate, or to compensate a low salary offer with attractive conditions. Therefore they are probably more variations and discrepancies on 
this part of the price than on salaries but they are also more difficult to evaluate as they are often more difficult to translate into monetary terms ${ }^{11}$.

\section{c) Universities, academics, price and quality}

Two main conclusions have been drawn at this stage. First, the market for professors is a specific market which can be qualified as an economy of quality. Second, on this kind of markets, the mechanisms of pricing differ from neoclassical mechanisms (the price is not set when supply meets demand) and they are not the same on different national academic labour markets. German universities define their prices under institutional constraints and rules. American universities look much more at the prices practised by their competitors and use this "price of the market" as their price.

This shows that the relationships between the price of the new professor and his/her quality as assessed by the hiring committee are rather loose. In the German case, the importance attributed to the discipline concerned and the "tariff" the recruiting institution is able to propose are more important than the "value" of the candidate. In the United States, the quality attached to the department, and the equivalence made with competitor departments is also more important than the judgement led by the hiring committee on the candidate ${ }^{12}$.

Such economic behaviours and types of labour market are probably not only observable in universities, but one can nevertheless suggest that such characteristics derive from their organisational specificities. They, more than other structures, have to manage the interactions and tensions between organisational and professional features and this is reflected in the distribution of the roles during the recruitment process and in the separation between 
judgement and pricing: the peers (profession) decide about whom will be integrated in the professional community while the leaders (organisation) behave as employers. The peers assess the academic (professional) value. The leaders are more aware of the institutional value.

\section{How do universities set the level of fees?}

In this third section I will now turn to the other market identified in the first section and consider the market for students. As for the market for professors, I shall focus on pricing and therefore look at fees. This time, I will not rely on original fieldwork but much more I will set the basis for a new potential research programme aimed at investigating the decision making process developed by universities to set their fees. Up to now, no study looked at this concrete process of "pricing in action". The available literature, on which this third section will draw upon, is essentially interested in the results of this process (how high are the fees) and the evolution of these results (do fees increase or not) rather than on pricing as a process or on the rationales of the actors involved in the determination of fees in higher education institutions.

Two main conclusions about fees may be derived from the existing literature. The first one concerns the increase in the level of fees as well as the expansion of the number of higher education institutions asking for fees, and thus the development of markets for students. The second deals with the underlying rationales that can be deduced from reading the existing literature on fees. 


\section{a) The expansion of the market for students: introduction and increase of fees}

According to the definition of market developed in the first point of the paper, many countries are still not experiencing a market for students. Higher education institutions compete for students but there is often no exchange around fees (or fees are often not considered as a price to pay for the training received). In France for instance, the level of fees first aims to cover the administrative costs implied by the registration of the students. But this situation is always changing. Two main evolutions have been occurring within the last decades. First in many countries fees have increased and they tend to be more and more conceived as reflecting (a share of) the cost of the training received. Second, fees have been introduced in countries where there were none. As stated at the beginning of the paper, the idea that training is a private good has spread.

Starting with countries where fees already existed, they experienced a rather important increase. In the United Kingdom for instance, after having introduced the idea of full cost for overseas students, the British governments started raising the limit of the maximum fees for undergraduates and proceeded by steps. The upper limit was first set at $1000 £$ in 1997 but since the 2004 Act higher education institutions have been allowed to ask to up to $3000 £$. This limit could disappear after 2010. While the last increase was accompanied by a reform of students' aid and by a policy in favour of access, the arguments justifying this evolution clearly revealed a conception promoting the transformation of students into consumers (Naidoo 2008), buying the positive gains they will individually get from training.

In the United States the transfer of the cost of education from the states to the families has also been massive within the last decades. In this country, the tradition for fees is well known 
and not new but a significant increase has been experienced over the last decades by the American system. According to the authors of a report published in 1999 by the Institute for Higher Education Policy (1999), fees were multiplied by five between 1976 and 1996 and almost doubled after adjusting for inflation. Increases in percentages and in dollars were higher in private institutions but the public sectors were also concerned. D. Ward and J. Douglass (2006) for instance estimate that between 1987 and 1997, fees increased by sixty percent in Texas, fifty-seven percent in North Carolina, forty-four percent in Illinois, etc. The 1999 report mentions that the share of fees in the resource structure of public universities went from thirteen to eighteen percent between 1980 and 1995 and from thirteen percent to forty-three percent in private institutions.

The figures observed in Germany are by no way comparable with the 30000 to 35000 dollars frequently asked by American private research universities, but the introduction of fees in some of the Länder is nevertheless a major change in a country where they did not exist before. Indeed, the Constitutional court decided in January 2005 that the Länder were responsible for introducing fees (or not) after five of them claimed for being recognized this right. Since September 2006 fees have thus been introduced in some German universities and today seven out of sixteen Länder ask for fees. In some cases, the public authorities of the Länder have fixed the level of fees by semester and in others they left rooms for the institutions to decide about what they will ask but in fact all (or almost all) opted for the same amount of 500 euros per semester (Ebcinoglu and Leszczensky 2008).

The variation among countries is thus considerable. Because there are no objective reasons for the price of training to be different between Germany and the United Kingdom, or between 
the United Kingdom and the United States, it is highly relevant to investigate the rationales behind the determination of the level of fees.

\subsection{Fees, a price of what?}

A quite similar issue has been raised by D. Ward and J. Douglass (2006) in a paper I will quite often quote in the following pages and in which they describe four models which can be used by leaders of a national/public higher education system to set the level of fees. They thus distinguished between the public versus private benefits model where prices should be set according to the private gains students can expect from their studies, the model of what the market will bear (as a complement of what the state bears), the model of national/international comparative norms and a model linked to some economic indicators such as the cost of living for instance. As stressed by these two authors, these models could be combined but it is also already possible to identify some country with a specific model.

My point of departure here will not be the same, as I will not consider this issue from the perspective of the public authorities but rather identify the different rationales that can be derived from the observation of the existing fees. Some of these rationales are comparable to the first three discussed by D. Ward and J. Douglass, others are rather different. There are also more than four.

\section{A political rational}


Even if the fees vary across countries in terms of level, they are everywhere influenced by the rationale of the "acceptable price", i.e. the price that payers can afford and accept. As a matter of fact, fees are a political issue. Notwithstanding the financial capacity of German families, it was of course impossible for the Länder introducing fees to go from zero to 30000 euros. We observed above how the United Kingdom experienced a progressive installation of increasing fees. Arguments, negotiations and rhetoric of different kinds ${ }^{13}$ have to be deployed in order to convince students, parents and the public opinion that training is a product that must be bought, and this takes time. It also takes time for the families to include and anticipate higher education expenses in their education budgets. It is highly probable that only very few German families would have saved 30000 euros in case high fees would be introduced. The issue of affordability therefore provides meaningful explanations for the huge differences observed among countries: those with the longest tradition can practice the higher fees and it is easier as well to transform fees into a price.

\section{Fees to compensate the increase in budget and the decrease in public funding}

The acceptability of the level of fees is not the only determinant. Further mechanisms can be observed from looking at the data. Another one can be described as the compensation of decreasing public funding in time of increasing training expenses ${ }^{14}$. Data in the United States show a clear correlation between the evolution of the public budgets and the level of fees. D. Ward and J. Douglass (2006: 7, graph 1) show that the California state recession in the public budget was followed by an increase in fees for public institutions. This is coherent with the evolution in the structure of resources of public and private universities reported by the Institute for Higher Education Policy (1999: 14). 
In Europe, the necessity of introducing fees is also often associated with the limitation of public resources, the latter being one of the arguments for the recourse to individual private contributions. Rather than "what the market bears", the crucial point here is about what the state can bear.

\section{The price of institutions to which one wants to be compared}

A third mechanism, which is compatible with the previous one, consists in anticipating the behaviours of other higher education institutions to set the price of one's own institution. This is again very close to the process described by H. White (1981) among producers looking at other producers to set their prices. It is exactly what happened in the United Kingdom when the maximum of fees has been fixed at $3000 £$. Data shows the strength of such mechanisms as almost all institutions decided to go up to $3000 £$. This resulted from two converging phenomena. The first one is the tendency of institutions to overestimate their reputation and quality. This had already been observed by T. Caplow and R. McGee (1958) when they asked university departments to cite departments they consider as equivalent to theirs in terms of reputation and attractiveness for job applicants: they tended to cite departments which were considered as better than theirs by external observers. I also noticed this bias in the departments where I led interviews in the United States about the price of academics: the departments they cited as their reference for the salary to be offered to an assistant professor were always more prestigious than theirs. The second phenomenon is less a question of cognition (in which category of departments do I locate myself) than a tactic: fearing that all 
other institutions will ask for the maximum, each institution decided to do the same in order not to be considered as of lesser quality if they were not asking for as high fees as the others.

The same mechanisms of comparable levels of fees is observable in the United States but there, the more formalised classification of institutions (research universities versus comprehensive versus etc. ) and the increasing division between private and public within each class of institutions lead to clustering effects: the private institutions of the same class (for instance research universities) propose roughly the same fees, while the public universities of this class also propose similar fees but which are lower than those of the private universities. Comparing the fees for undergraduates required by eleven private research universities in 2003 and 2004, D.Ward and J Douglass (2006: 12) for instance showed that they vary from 28400 to 31040 for ten of them. But as for salaries, the relationship between the price and quality is not simple. The more reputed are not more expensive than the others. Brown university (which was ranked $82^{\text {th }}$ in the 2004 Shanghai ranking) for instance asked for 29,846 \$ in 2003-2004 and while Harvard (which ranked $1^{\text {st }}$ ) asked for 29,060 .

\section{Fees according to the expected individual gains for the students}

A fourth mechanism which can be derived from the data consists of linking fees with the expected gains of the students in terms of subsequent salaries. This is not clearly implemented in all universities but, again, the figures provided by D. War and J. Douglass (2006) about the United States are very helpful, as they display the fees required by type of studies in eleven private and fourteen public research universities. Some programmes are considerably more 
expensive in law than in nursing or theater and film (in one of them the ratio is of 1 to respectively $1 / 4$ and $2 / 3^{\text {rd }}$ ) but in many the difference is very little if any.

In Europe, the introduction of the two-tier structure has led to a comparable trend and to a stronger distinction between the undergraduates courses where fees are low and the master programs for which more differentiated prices are available in the same institution for different disciplines. Here again the fees may be read as a mirror of the expected gains. Gains in the future: in a continental Europe university for instance, the fees for a MBA reach 26000 euros per year while a Master in Modern European language can be obtained for about 1600 euros.

Fees according to the costs of production

A fifth mechanism influencing the level of fees is the cost of a training programme. The differentiated costs of a class in science and a class in humanities were often taken into account by public authorities in their allocation of public funding. In France, for instance, the budgets have long been calculated according to the number of students, and the cost by student varied according to the disciplines. Conversely, one could expect more expensive programmes to ask for higher fees. But it is still rare to calculate fees according to the level of "full costs" of a training programme.

Fees according to marketing strategies 
In the competition for students, fees are also used in order to attract some categories of students rather than others. This is very close to the "the price of institutions to which one wants to be compared with" in the sense that fees (and the financial aid programmes) are used as a signal to identify the kind of institution the student will attend (Kraatz and Ventresca 2003).

Fees to make profit

Last but not least, fees may be set, not only to cover (totally or partially) the costs, but to increase the benefits, as can be expected from for-profit private institutions.

All these observations converge to show that when it is possible to speak of a market for students (i.e. when fees are considered as reflecting, partially or totally, the price of attending a training programme), we may observ rather different ways about calculating this price.

From this point of view we are confronted with an interesting but puzzling market. Further research on the process by which institutions set their price would help better understanding how price are decided upon within these institutions and how these rationales are mixed and combined.

\section{Conclusion}

The two main arguments of this paper can be summed up as follows. First, we should be more analytical in our analysis of markets in higher education and not confound competition with 
markets or exchanges with markets. Both conditions (competition and exchange) have to be present to speak of markets.

Second, when there are markets, one needs to look at how they concretely work. As for other markets, markets in higher education display a pretty wide range of alternatives and are quite far from being perfect markets according to the definition of neo-classical economics. We observed that academic labour markets are an interesting form of an economy of quality on which institutions set their own price or look at the price of the market.

Markets for students are even more particular. They are characterized by the multiple ways and rationales which can lead to a price, as if no single calculation could be identified. This links of course to the political nature of the fees and their link to issues of access, equality and equity. But even when these aspects are less pregnant, there remain competing possibilities, probably because of the ambiguous nature of training as a product.

\section{References}

Aust, J., \& Crespy, C. (forthcoming). Napoléon renversé. Institutionalisation des PRES et réforme de l'enseignement supérieur et de la recherche en France, Revue Française de Science Politique.

Brunsson, N., \& Shalin-Andersonn, K. (2000). Constructing organisations: the example of public reform sector. Organisation Studies, 2000, 4, 721-746.

Caplow, T., \& McGee, R. (1958). The Academic Marketplace. Garden City: Doubleday.

Charle, C., \& Soulié, C. (2008). Les ravages de la modernisation universitaire en Europe. Paris: Editions Sylepse. 
Doeringer, P. B., \& Piore, M. J.(1971). Internal labor Markets and Manpower Analysis. Lexington: Heath Lexington Books.

Ebcinoglu, F., \& Leszczensky, M. (2008). Studiengebühren in Deutschland und Europa. Forschung und Lehre, 15(1), 12-14

François, P. (2008). Sociologie des marchés. Paris: Armand Colin.

Frank, D.J. \& Meyer, J.W. (2006). Worlwide Expansion and Change in the University. In G. Krücken, A. Kosmützky \& M. Torka (Eds.), Towards a Multiversity? Universities between Global Trends and national Traditions (19-44) Bielefeld: Transcript Verlag.

Institute for Higher Education Policy (1999). The Tuition Puzzle. Putting the Pieces Together, The New Millennium Project on Higher Education Costs, Pricing, and Productivity.

Karpik, L. (1989). L'économie de la qualité. Revue française de sociologie, 30(2), 187-210.

Karpik, L. (1995). Les avocats. Entre l'Etat, le public et le marché - XIIIème-XXème siècles. Paris: Gallimard.

Karpik, L. (2007). L’économie des singularités. Paris, Gallimard.

Kraatz, M. S. \& Ventresca, M. (2003). Toward the Market driven University? Pragmatic Institutionalism and the Spred of Enrollment Management. Scancor Conference on "Universities an the Production of Knowledge", Stanford University.

Krücken, G., \& Meier, F. (2006). Turning the University into an Organizational Actor. In G.

Drori, J. Meyer \& H. Hwang (Eds.), Globalization and Organization (241-257), Oxford: Oxford University Press.

Lant, T. K., \& Baum, J. A. C. (2003). Hits and Misses: Managers' (Mis)Categorization of Competitors in the Manhattan Hotel Industry. Advances in Strategic Management: Geography and Strategy, 20, 119-156.

Mallard, G. (2006). Quand l'expertise se heurte au pouvoir souverain: la nation américaine face à la prolifération nucléaire, 1945-1953. Sociologie du travail, 48(3), 367-389 
Musselin, C. (1996). Les marchés du travail universitaires comme économie de la qualité. Revue française de sociologie, 37(2), 189-207.

Musselin, C. (2001). La longue marche des universités françaises. Paris, PUF. (published in 2004 as The Long March of French Universities, New York : Routledge).

Musselin, C. (2004). Towards a European Academic Labour Market?, Some Lessons drawn from Empirical Studies on Academic Mobility. Higher Education, 48, 55-78.

Musselin, C. (2005). Les marchés du travail universitaires. France, Allemagne, Etats-Unis. Paris: Presses de Sciences-Po.

Musselin, C. (2006). Are Universities specific organizations?. In G. Krücken, A. Kosmützky \& M. Torka (Eds.), Towards a Multiversity? Universities between Global Trends and national Traditions (63-84) Bielefeld: Transcript Verlag.

Musselin, C., \& Paradeise, C. (2002). Le concept de qualité: où en sommes-nous ?. Sociologie du travail, 44(2), 255-260.

Naidoo, R. (2008). La réforme de l'enseignement supérieur au Royaume-Uni. Critique Internationale, 39, 47-65.

Rhoades, G., \& Slaughter, S. (2004). Academic Capitalism and the New Economy: Markets, State and Higher Education. Baltimore: The Johns Hopkins University Press.

Slaughter, S., \& Leslie, L. (1997). Academic capitalism: politics, policies and the entrepreneurial university. Baltimore: The Johns Hopkins University Press.

Sørensen, A. B. (1993). «Wissenschaftliche Werdegänge und akademische Arbeitsmärkte. In K.-U. Mayer (Ed.), Generationsdynamik in der Forschung (83-109). Francfort: Campus Verlag,

Swedberg, R. (1998). Max Weber and the Idea of Economic Sociology. Princeton: Princeton University Press. 
Ward, D., \& Douglass, J. (2006). Higher Education and the Specter of Variable Fees: Public

Policy and Institutional Responses in the United States and United Kingdom. Higher Education Management and Policy, 18(1), 1-28.

Weber, M. (1995/1922). Economie et Société. Paris : Pocket.

White, H. C. (1981). Where do Markets Come from?. American Journal of Sociology, 87(3), $517-547$. 


\section{Table}

Evolution of the structure of resources in public and private American universities (built on Institute for Higher Education Policy, 1999: 14)

\begin{tabular}{|l|c|c|}
\hline \multicolumn{1}{|c|}{} & $\mathbf{1 9 8 0 - 1 9 8 1}$ & $\mathbf{1 9 9 4 - 1 9 9 5}$ \\
\hline Public universities & & $51 \%$ \\
\hline Public revenues & $63 \%$ & $18 \%$ \\
\hline Fees & $13 \%$ & \\
\hline Private universities & & $17 \%$ \\
\hline Public revenues & $22 \%$ & $42 \%$ \\
\hline Fees & $37 \%$ & \\
\hline
\end{tabular}

${ }^{1}$ While equality and uniformity were the main characteristics of the French university systems, differentiation and diversity by contrast prevailed in the sector of the so-called Grandes Ecoles in France!

${ }^{2}$ The two processes aim at selecting top projects and universities which will receive funding but the German process is more selective, is more research oriented and more money is at hand than in the French case.

${ }^{3}$ It is moreover relevant to speak of "price" as not only salaries are negotiated between the candidate and the university but also the working conditions which will be at disposal (budget for books, number of research assistants, access to secretariat, etc.) and in some countries some personal benefices (preferential loans to buy a house, help in finding a job for the spouse, etc.) 
${ }^{4}$ In France for instance, such negotiations almost never occur in universities. The salary is set according to a national nonflexible scale.

${ }^{5}$ Even in France where all baccalauréat holders can attend a university, competition for students exists between the universities and the grandes écoles on the one hand and between the few selective and the many non selective training programmes within universities.

${ }^{6}$ More recent, but also less extended, fieldwork in Germany will complete this previous study.

${ }^{7}$ Up to now, only a limited share of the professors is concerned as merit-salaries and the new salary-scales are introduced only for those newly becoming professors and for the already professors moving from one institution to another.

${ }^{8}$ It is all the more so that in order to introduce more flexible wages a range of min and max salary for a professor has been defined for each university, based on the income budget they had for their professors before the reform. This range of salary thus varies from institution to another, from one Länder to another, depending on the more or less wealthy situation of the institution before.

${ }^{9}$ Assistant professor is the first available positions « on tenure track », i.e. on the career path leading to a tenured position.

${ }^{10}$ I will focus on negotiation for assistant professors because these are the more common negotiations occurring. It is rarer to recruit senior professors and for that reason, the number of cases of senior recruitment I could work on is very limited and not reliable enough.

${ }^{11}$ How for instance compare the value of getting help for your spouse to find a job with an agreement to spend the first year away in order to reinforce your research capacity and start teaching only one year latter? 
12 This not to say that the quality of the candidate does not play at all. Candidates who are ranked first by two or more institutions can of course bargain more.

${ }^{13}$ For instance about the limits of the state budget, about the unfair social redistribution provoked by the absence of fees, the inefficiency of the no fees policy to fight against elite reproduction, etc.

${ }^{14}$ Expenses increase in all countries for different reasons. First because of the massification of higher education (Frank and Meyer, 2006) training has to be provided to more and more students. In countries with a free public system this mathematically increases the higher education budget. Furthermore, the training technologies are more and more expensive. Blackboard and chalks are for instance no more sufficient. All classrooms have to be equipped with video projectors, computers, wifi etc. 